\title{
Study on Feeding Effect of Different Levels of Protein and Energy on Production Performance of Pregnant Mother and Neo-Natal Calves
}

\author{
Nathu Ram Sarker, Muhammad Khairul Bashar, Sheik Mohammad Jahangir Hossain, Mohammed Khorshed \\ Alam and Khan Shahidul Huque \\ Animal Production Research Division, Bangladesh Livestock Research Institute, Savar, Dhaka-1341, Bangladesh
}

\begin{abstract}
The present study was undertaken to assess feeding effect on productive and reproductive performances of pre-natal and post-natal Red Chittagong Cattle (RCC) cows under on-station condition. A total of 16 pregnant RCC cows having pregnancy 6-7 months and between 1-3 parities was selected for the study and was allocated randomly into four dietary treatment groups. There are four type diets, i.e., $\mathrm{T}_{0}$ (standard diet according to National Research Council (NRC), 1995), $\mathrm{T}_{1}$ (5\% below standard diet), $\mathrm{T}_{2}(5 \%$ above standard diet), $\mathrm{T}_{3}\left(10 \%\right.$ above standard diet) and a control treatment $\mathrm{T}_{4}$ (maintained as farm practice). The energy and protein requirements of experimental cows were determined as per standard developed by NRC. The results revealed that crude protein (CP) and metabolizable energy (ME, MJ/day) requirements among cows of different dietary groups were not significantly different, although CP requirements between $\mathrm{T}_{1}$ and $\mathrm{T}_{3}$ differed significantly. Total dry mater (DM) and ME intake differed significantly $(P<$ 0.001) among cows of different dietary groups, but DM intake was significantly lower for cows in farm practice group $T_{4}$ compared to the cows of other dietary groups. The total $C P$ intake had no significant variation $(P>0.05)$ among cows of all dietary groups, but $\mathrm{CP}$ intake from roughage varied significantly $(P<0.001)$. Final live weight and total live weight gain had no significant variation for cows of all groups, but there were significant $(P<0.05)$ variation for daily weight gain. Daily weight gain of cows for first four dietary groups were significantly $(P<0.05)$ higher than cows of farm practice groups $\mathrm{T}_{4}$. Weight of calf from birth to 90 days and daily weight gain calves under different dietary groups showed that there were no significant $(P>0.05)$ variation of calf birth weights for all dietary groups, although lower birth weight was found in farm practice groups $\mathrm{T}_{4}$. Gestation length and postpartum heat period of cows of different dietary treatment groups revealed that there was no significant $(P>0.05)$ variation for those traits among cows of different dietary treatment groups, although there seems to be shorter postpartum heat for cows in dietary group $\mathrm{T}_{2}$ and longer period in farm practice group $\mathrm{T}_{4}$. Total and daily milk yield up to 30 days and 90 days of cows had no significant $(P>0.05)$ effect for different dietary treatment groups, although there seems to be slightly better milk production performance for dietary $T_{2}$ and $T_{0}$, respectively for 30 days and 90 days total and daily milk yield. There were no significant $(P>0.05)$ changes of total and daily weight gain of cows for all dietary groups, however cows of standard dietary group $\mathrm{T}_{0}$ performed slightly better than those of cows of other dietary groups. Milk composition of cows of different dietary treatment groups showed that there was no significant $(P>0.05)$ variation on milk composition for cows of different dietary groups. Post-natal body condition score (BCS) for the 1st, 3rd and 4th months differed significantly $(P<0.05)$ among different dietary groups, while not found significant difference on the 2nd month. Therefore, it may be concluded that pre-natal feeding has significant effect on body weight gain, birth weight of calves and milk production of dairy cows. Hence, it is suggested that better nutrition may be provided during pre-natal period to harvest good quality of calves and higher milk yield from post-natal period.
\end{abstract}

Key words: Pre-natal, post-natal, postpartum heat period, gestation length, milk yield.

\section{Introduction}

Care of the dairy animal's starts with the birth of

Corresponding author: Nathu Ram Sarker, Ph.D., research fields: animal nutrition and feeds and forage technology. E-mail: sarkernr62@yahoo.com. the calf. The animals need ideal conditions to exhibit their inherent genetic capabilities. The birth weight of the calf affects the subsequent growth rate. The heavier calf gains weight at a faster rate than the calf with lower birth weight, even if both are given 
adequate nutrition. Although the effects of nutrition, housing and health care are of much greater importance, each $1 \mathrm{~kg}$ difference in birth weight will expand to about $1.5 \mathrm{~kg}$ difference by 12 weeks of age [1]. Requirements for pregnancy represent nutrients necessary to support both growth and maintenance of fetus, placenta, uterus and mammary gland. Last two months of pregnancy needs special care in terms of higher provision of essential nutrients. Various immunological and biochemical adjustments take place in the dam to meet the metabolic needs of fetus and neonates for growth and development. During fetal life, there is maternal protection; and in the post-natal life, the neonates are protected from mother and nourished by the colostrums and milk. The influence of maternal nutrition on the early growth performance of offspring's is mainly mediated through its influence on the birth weight besides milk yield and quality. Although there are many studies that have demonstrated a positive impact of maternal nutrition on the birth weight of calves [2-4], its effects on the early growth performance of the calves is often without agreement. There are positive reports of the effect of maternal plane of nutrition on growth performance of calves. Red Chittagong Cattle (RCC) is a potential dairy cattle variety of Bangladesh and is suitable for smallholder farmers due to its small size and low feed requirements $[5,6]$. They are reared under poor quality diet, unbalanced nutrients, improper feeding and poor husbandry management practice and their performances are very poor [6]. Ahmed [7] reported that the nutritional status of indigenous cows is still remaining low. RCC in farming systems are reared under traditional feeds, feeding and management practices [6]. Ahmed [7] reported the nutritional status of RCC cows remains low because they are underfed due to scarcity of feeds, fluctuated feed supply as well as absence of scientific feeding practices to improve cows performances. Ahmed [7] also reported that the nutrition is a prerequisite for the normal function of the organs involved in productive and reproductive performances of the cows. In an experiment, Ziegler [8] reported that underfed cows are slow to return to normal heat cycles and have lower conception rates when bred. Lack of nutrient intake, i.e., energy and/or protein, is the greatest causes of poor reproductive performance. Ziegler [8] also reported that the pre-calving nutrition of the mother cow has many important implications in proper fetal growth, calf health at birth, the resistance of calf to stress and diseases when a cow produces milk and/or lactates. Maternal nutritional plane $[9,10]$ has been implicated in developmental programming and results pre-natal and post-natal changes that long term affect offspring's health and performance. Developmental programming is the concept that perturbations during critical pre-natal or post-natal developmental stages can have lasting impacts on growth and adult function. Maternal nutritional status [10-13] is a major factor implicated in development and function of the fetal organ systems. Effective nutritional [14-19] management during gestation has long been recognized as an important component of sound livestock production practices. Shamsuddin et al. [20] reported that imbalance feeding has been shown to be one of the factors for high incidence of reproductive disorders in the cows, which could be alleviated by supplying improved and balanced diet. Lotthammer [21] reported that the normally pregnant cows face two types of stress-firstly during pregnancy its body reserves of nutrients are reduced due to fetal development, and secondly just after the initiation of lactation period, sudden secretion of nutrients into milk is also responsible for stress to the cows. So, during this period, they need more nutrients. Jalil et al. [22] indicated that improved feeding has a positive effect on reproductive performances including milk production. Asaduzzaman et al. [23] also reported that improved feeding during pregnant and lactating of RCC cows compared to traditional feeding significantly increased live weight gain of RCC cows and their calves. Milk yield, fat-corrected 
milk and milk composition were also increased. The results further indicated that there was significant $(P<$ 0.05 ) effect of improved feedings on reproduction performances of the cows. The better reproductive performance was observed in $100 \%$ requirement group. It also showed that there was a significant $(P<$ 0.01) difference in feed cost among the three dietary treatment groups. Income from sale of milk varied significantly $(P<0.01)$ among the different treatment groups, while it was higher in $\mathrm{T}_{2}$ (213.30) group, followed by $\mathrm{T}_{1}(109.20)$ and $\mathrm{T}_{0}$ (74.70) groups.

However, the nutritional status of RCC cows so far has not been studied in our country. Therefore, with the above views in mind, the present study was undertaken with the following objectives:

To determine the nutritional requirement of RCC during later part of pregnancy;

To assess the feeding effect on productive and reproductive performances of pre-natal and post-natal RCC cows and their progeny.

\section{Materials and Methods}

\subsection{Statement of the Experiment}

The experiment was conducted for the period of one year from July 2012 to June 2013 to investigate the feeding effect on productive and reproductive (preand post-natal) performance improvement of RCC cows.

\subsection{Selection of Experimental Cows}

A total of 16 pregnant RCC cows are collected from the Bangladesh Livestock Research Institute (BLRI) farm and reared in shed. Four pregnant RCC cows were accommodated in a group. Four cows kept in a group are considered as an experimental unit (replication).

\subsection{Weighing of the Cows}

The experimental pregnant RCC cows were weighed individually at fortnightly interval by using digital cattle weighing scales from the start. The weight was recorded in the register. The weighing of the cows was performed early in the morning before feeding, and their calves were also weighed individually at weekly interval by using digital cattle weighing scales from the start and recorded in the resister.

\subsection{Calculation Daily Nutrient Requirements of Pregnant RCC Cows}

The daily dry matter requirements $(D M R)$, crude protein requirements $(C P R)$ and metabolizable energy requirements $(M E R)$ of the pregnant RCC cows are calculated. A nutrient requirement was calculated on the basis of National Research Council (NRC) standard. The calculations of the nutritional requirements are shown below:

$$
D M R(\mathrm{~kg} / \mathrm{d})=M E / M E C
$$

where, $M E C=$ metabolizable energy concentration in intake diet dry matter of feeding.

$$
C P R(\mathrm{~g} / \mathrm{d})=R D P+U D P
$$

where, $R D P=$ rumen degradable protein and $U D P=$ undegradable dietary protein.

$$
\operatorname{MER}(\mathrm{MJ} / \mathrm{d})=M E_{m}+M E_{f}
$$

where, $M E_{m}=$ total $M E R$ for maintenance and $M E_{f}=$ total MER for fetus development.

\subsection{Feeding Trial with Pregnant Mother and Neo-Natal Calves}

A feeding trial is conducted with selected pregnant mother as per design of the experiment. There are four type diets-standard diet (according to NRC), 5\% below standard diet, $5 \%$ above standard diet and 10\% above standard diet, will be used in this experiment (Table 1). A total of 16 pregnant RCC cows is divided into four equal groups and will be assigned to four dietary treatments. Four cows in each treatment are used as three replicates. Roughage (green grass and straw) are supplied to the experimental cows twice daily at 9:00-10:00 am and 3:00-4:00 pm. Green grass are supplied ad libitum and straw supplied 2 $\mathrm{kg} / \mathrm{d} / \mathrm{cow}$. Concentrate mixture are supplied to the 
Table 1 Lay out of the experiment.

\begin{tabular}{|c|c|c|c|c|c|}
\hline \multirow[b]{2}{*}{$\begin{array}{l}\text { Group (length of } \\
\text { pregnancy) }\end{array}$} & \multicolumn{4}{|c|}{ Treatments } & \multirow[b]{2}{*}{ Total } \\
\hline & $\begin{array}{l}\mathrm{T}_{0} \\
\text { (standard diet } \\
\text { according to NRC) }\end{array}$ & $\begin{array}{l}\mathrm{T}_{1} \\
(5 \% \text { below standard } \\
\text { diet }) \\
\end{array}$ & $\begin{array}{l}\mathrm{T}_{2} \\
(5 \% \text { above standard } \\
\text { diet }) \\
\end{array}$ & $\begin{array}{l}\mathrm{T}_{3} \\
(10 \% \text { above standard } \\
\text { diet })\end{array}$ & \\
\hline $\begin{array}{l}\text { Replication } 1 \\
\text { (4-5 months) }\end{array}$ & (2) & 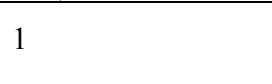 & ( & 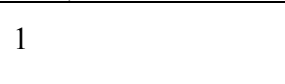 & 4 \\
\hline $\begin{array}{l}\text { Replication } 2 \\
\text { (5-6 months) }\end{array}$ & 1 & 1 & 1 & 1 & 4 \\
\hline $\begin{array}{l}\text { Replication } 3 \\
\text { (6-7 months) }\end{array}$ & 2 & 2 & 2 & 2 & 8 \\
\hline Total & 4 & 4 & 4 & 4 & 16 \\
\hline
\end{tabular}

experimental cows twice daily at 8:00-8:30 am and 2:30-3:00 pm. Concentrate mixture is required $18.77 \%$ $\mathrm{CP}$ and 10.39 MJ ME per kg of feed. Management practices of the pregnant RCC cows under the experiment are all most similar. The mixture of concentrate comprises the different ingredients, such as crushed maize, wheat bran, soyabean meal, sesame oil cake, Khesari (Lathyrus sativas) bran, common salt and dicalcium phosphate at the ratio of $19 \%, 40 \%, 9.5 \%, 17 \%, 1.5 \%$ and $2.5 \%$, respectively, to maintain requirement level of $\mathrm{ME}$ and $\mathrm{CP}$ for $\mathrm{RCC}$ pregnant cows. The live weight was taken individually at fortnightly with the help of a portable digital cattle weighing scale.

\subsection{Body Condition Score (BCS)}

BCS of the experimental cows were carried using visual and palpation technique according to the guidelines established by Prasad and Tomer [3]. This method grades the cow's conditioning status on a six-point scale (1-6), where 1 reflects very thin and 6 reflects very fat animal. Cows' body condition was scored on the day of their inclusion in the experiment and after 30 days interval till the end of the experiment.

\subsection{Data Analysis}

The collected data were analyzed by using SPSS 13.0 for Windows (SPSS Inc., 2004) statistical package and treatment means comparison were assessed by Duncan's multiple range test (DMRT) to test the significance among the treatment.

\section{Results and Discussion}

Feed and nutrients intake of pre-natal cows of different treatment groups are given in Table 2. Intake of straw, green grass and concentrates were significantly $(P<0.001)$ different among cows of different dietary groups. Except of cows reared in farm practices, intake of straw, green grass and concentrates of other dietary groups had no significant variation. $\mathrm{CP}$ and $\mathrm{ME}$ requirements among cows of different dietary groups were not significant, although $\mathrm{CP}$ requirements between $\mathrm{T}_{1}$ and $\mathrm{T}_{3}$ differed significantly. Total dry matter (DM) intake and ME intake differed significantly $(P<0.001)$ among cows of different dietary groups. In all cases, intake was significantly lower for cows in farm practice group $\left(\mathrm{T}_{4}\right)$ than those of cows of other dietary groups. Although total CP intake had no significant variation $(P>0.05)$ among cows of all dietary groups, but $\mathrm{CP}$ intake from roughage varied significantly $(P<0.001)$.

Pre-natal growth of RCC cows of different dietary treatment groups are given in Table 3, which shows initial live weight. Final live weight and total live weight gain had no significant variation for cows of all groups, but there were significant $(P<0.05)$ variation for daily weight gain. Daily weight gain of cows for first four dietary groups were significantly $(P$ $<0.05)$ higher than cows of farm practice groups $\left(\mathrm{T}_{4}\right)$.

Weight of calf from birth to 90 days and weight gain born in different dietary dam groups are given in Table 4. Table 4 shows that there were no significant $(P>0.05)$ variation of calf birth weights for all dietary 
Table 2 Feed and nutrient intake of pre-natal RCC from different diets.

\begin{tabular}{|c|c|c|c|c|c|c|c|}
\hline \multirow[b]{2}{*}{ Parameters } & \multicolumn{6}{|c|}{ Mean $( \pm$ SE) for different treatment groups } & \multirow[b]{2}{*}{ Sig. } \\
\hline & $\begin{array}{l}\mathrm{T}_{1} \\
\text { (below 5\%) }\end{array}$ & $\begin{array}{l}\mathrm{T}_{0} \\
\text { (standard) }\end{array}$ & $\begin{array}{l}\mathrm{T}_{2} \\
\text { (above 5\%) }\end{array}$ & $\begin{array}{l}\mathrm{T}_{3} \\
\text { (above } 10 \% \text { ) }\end{array}$ & $\begin{array}{l}\mathrm{T}_{4} \\
\text { (farm practice) }\end{array}$ & Overall & \\
\hline Straw (kg) & $1.57 \pm 0.05$ & $1.63 \pm 0.03$ & $1.63 \pm 0.05$ & $1.59 \pm 0.04$ & 0.00 & $1.28 \pm 0.15$ & NS \\
\hline Green grass $(\mathrm{kg})$ & $18.49^{\mathrm{a}} \pm 0.42$ & $19.08^{\mathrm{a}} \pm 0.30$ & $19.55^{\mathrm{a}} \pm 0.55$ & $19.19^{\mathrm{a}} \pm 0.44$ & $15.64^{\mathrm{b}} \pm 0.18$ & $18.39 \pm 0.36$ & *** \\
\hline $\begin{array}{l}\text { Feed concentrate } \\
(\mathrm{kg})\end{array}$ & $3.00^{\mathrm{a}} \pm 0.33$ & $3.08^{\mathrm{a}} \pm 0.06$ & $3.49^{\mathrm{a}} \pm 0.15$ & $2.88^{\mathrm{a}} \pm 0.33$ & $1.50^{\mathrm{b}} \pm 0.00$ & $2.79 \pm 0.18$ & $* * *$ \\
\hline $\begin{array}{l}\text { CP requirements } \\
(\mathrm{g} / \mathrm{d})\end{array}$ & $405.86^{\mathrm{b}} \pm 37.79$ & $468.36^{\mathrm{ab}} \pm 12.36$ & $496.21^{\mathrm{ab}} \pm 52.68$ & $515.28^{\mathrm{a}} \pm 28.52$ & $442.28^{\mathrm{ab}} \pm 15.21$ & $465.59 \pm 15.80$ & $* *$ \\
\hline $\begin{array}{l}\text { ME requirements } \\
(\mathrm{MJ} / \mathrm{d})\end{array}$ & $46.17 \pm 2.29$ & $46.59 \pm 0.89$ & $48.39 \pm 2.24$ & $46.98 \pm 0.39$ & $50.85 \pm 2.54$ & $47.79 \pm 0.84$ & NS \\
\hline $\begin{array}{l}\text { DM intake from } \\
\text { roughage }(\mathrm{kg} / \mathrm{d})\end{array}$ & $4.34^{\mathrm{a}} \pm 0.10$ & $4.49^{\mathrm{a}} \pm 0.07$ & $4.55^{\mathrm{a}} \pm 0.13$ & $4.46^{\mathrm{a}} \pm 0.11$ & $2.53^{\mathrm{b}} \pm 0.03$ & $4.07 \pm 0.18$ & $* * *$ \\
\hline $\begin{array}{l}\text { DM intake from } \\
\text { concentrate }(\mathrm{kg} / \mathrm{d})\end{array}$ & $2.68^{\mathrm{a}} \pm 0.29$ & $2.75^{\mathrm{a}} \pm 0.05$ & $3.13^{\mathrm{a}} \pm 0.14$ & $2.57^{\mathrm{a}} \pm 0.29$ & $1.34^{\mathrm{b}} \pm 0.00$ & $2.49 \pm 0.16$ & *** \\
\hline $\begin{array}{l}\text { Total DM intake } \\
(\mathrm{kg} / \mathrm{d})\end{array}$ & $7.02^{\mathrm{a}} \pm 0.24$ & $7.24^{\mathrm{a}} \pm 0.09$ & $7.68^{\mathrm{a}} \pm 0.24$ & $7.04^{\mathrm{a}} \pm 0.34$ & $3.87^{\mathrm{b}} \pm 0.03$ & $6.57 \pm 0.33$ & $* * *$ \\
\hline $\begin{array}{l}\text { ME intake from } \\
\text { roughage }(\mathrm{MJ} / \mathrm{d})\end{array}$ & $29.77^{\mathrm{a}} \pm 0.43$ & $30.09^{\mathrm{a}} \pm 0.06$ & $30.69^{a} \pm 0.62$ & $30.20^{\mathrm{a}} \pm 0.48$ & $22.79^{b} \pm 0.25$ & $28.71 \pm 0.70$ & $* * *$ \\
\hline $\begin{array}{l}\mathrm{ME} \text { intake from } \\
\text { concentrate }(\mathrm{MJ} / \mathrm{d})\end{array}$ & $21.00^{\mathrm{a}} \pm 2.31$ & $21.55^{\mathrm{a}} \pm 0.039$ & $24.48^{\mathrm{a}} \pm 1.08$ & $20.14^{\mathrm{a}} \pm 2.28$ & $13.15^{\mathrm{b}} \pm 0.00$ & $20.07 \pm 1.06$ & $* *$ \\
\hline $\begin{array}{l}\text { Total ME intake } \\
(\mathrm{MJ} / \mathrm{d})\end{array}$ & $50.77^{\mathrm{a}} \pm 1.99$ & $51.64^{\mathrm{a}} \pm 0.38$ & $55.18^{\mathrm{a}} \pm 1.59$ & $50.34^{\mathrm{a}} \pm 2.39$ & $35.93^{\mathrm{b}} \pm 0.27$ & $48.77 \pm 1.65$ & $* * *$ \\
\hline $\begin{array}{l}\text { CP intake from } \\
\text { roughage }(\mathrm{g} / \mathrm{d})\end{array}$ & $271.02^{\mathrm{c}} \pm 4.18$ & $281.38^{c} \pm 4.18$ & $309.18^{\mathrm{b}} \pm 6.98$ & $310.05^{\mathrm{b}} \pm 8.83$ & $341.88^{\mathrm{a}} \pm 3.75$ & $302.70 \pm 6.49$ & $* * *$ \\
\hline $\begin{array}{l}\text { CP intake from } \\
\text { concentrate }(\mathrm{g} / \mathrm{d})\end{array}$ & $144.56^{\mathrm{b}} \pm 19.10$ & $162.72^{\mathrm{ab}} \pm 6.0$ & $164.50^{\mathrm{ab}} \pm 26.55$ & $200.36^{a} \pm 18.14$ & $121.00^{\mathrm{b}} \pm 0.00$ & $158.69 \pm 9.01$ & NS \\
\hline $\begin{array}{l}\text { Total CP intake } \\
(\mathrm{g} / \mathrm{d})\end{array}$ & $415.58 \pm 30.25$ & $444.10 \pm 9.55$ & $473.68 \pm 33.79$ & $510.41 \pm 24.92$ & $384.82 \pm 76.45$ & $445.72 \pm 19.31$ & NS \\
\hline
\end{tabular}

$\mathrm{NS}=P>0.05 ; * *=P<0.01 ; * * *=P<0.001$. Sig.: significance level.

Table 3 Feeding effect on live weight change of prenatal RCC.

\begin{tabular}{llllllll}
\hline \multirow{2}{*}{ Parameters } & \multicolumn{7}{c}{ Mean $( \pm \mathrm{SE})$ for different treatment groups } \\
\cline { 2 - 8 } & $\begin{array}{l}\mathrm{T}_{1} \\
(\text { below 5\%) }\end{array}$ & $\begin{array}{l}\mathrm{T}_{0} \\
(\text { standard })\end{array}$ & $\begin{array}{l}\mathrm{T}_{2} \\
(\text { above 5\%) }\end{array}$ & $\begin{array}{l}\mathrm{T}_{3} \\
(\text { above 10\%) }\end{array}$ & $\begin{array}{l}\mathrm{T}_{4} \\
\text { (farm practice) }\end{array}$ & Overall & Sig. \\
\hline Initial weight $(\mathrm{kg})$ & $160.25 \pm 15.26$ & $179.25 \pm 9.85$ & $197.00 \pm 22.87$ & $169.00 \pm 14.95$ & $173.75 \pm 9.27$ & $175.85 \pm 6.68$ & $\mathrm{NS}$ \\
Final weight $(\mathrm{kg})$ & $199.63 \pm 12.28$ & $217.06 \pm 10.67$ & $245.25 \pm 36.13$ & $208.05 \pm 16.97$ & $203.75 \pm 10.64$ & $214.75 \pm 8.73$ & $\mathrm{NS}$ \\
Total weight gain $(\mathrm{kg})$ & $39.38 \pm 5.79$ & $37.81 \pm 7.38$ & $48.25 \pm 13.74$ & $39.05 \pm 2.16$ & $30.00 \pm 1.83$ & $38.89 \pm 3.28$ & $\mathrm{NS}$ \\
Daily weight gain $(\mathrm{kg} / \mathrm{d})$ & $0.429^{\mathrm{a}} \pm 0.05$ & $0.412^{\mathrm{a}} \pm 0.07$ & $0.470^{\mathrm{a}} \pm 0.06$ & $0.464^{\mathrm{a}} \pm 0.08$ & $0.200^{\mathrm{b}} \pm 0.01$ & $0.395 \pm 0.03$ & $*$ \\
\hline
\end{tabular}

NS $=P>0.05 ; *=P<0.05$. Sig.: significance level.

Table 4 Feeding effect on birth weight $(\mathrm{kg})$ and average daily gain of calves.

\begin{tabular}{|c|c|c|c|c|c|c|c|}
\hline \multirow[b]{2}{*}{ Parameters } & \multicolumn{6}{|c|}{ Mean $( \pm$ SE) for different treatment groups } & \multirow{2}{*}{$\begin{array}{l}\text { Sig. } \\
\text { level }\end{array}$} \\
\hline & $\begin{array}{l}\mathrm{T}_{1} \\
\text { (below 5\%) }\end{array}$ & $\begin{array}{l}\mathrm{T}_{0} \\
\text { (standard) }\end{array}$ & $\begin{array}{l}\mathrm{T}_{2} \\
\text { (above 5\%) }\end{array}$ & $\begin{array}{l}\mathrm{T}_{3} \\
\text { (above 10\%) }\end{array}$ & $\begin{array}{l}\mathrm{T}_{4} \\
\text { (farm practice) }\end{array}$ & Overall & \\
\hline Calf birth weight $(\mathrm{kg})$ & $15.43^{\mathrm{ab}} \pm 0.55$ & $15.68^{\mathrm{a}} \pm 0.38$ & $16.60^{\mathrm{a}} \pm 2.34$ & $14.67^{\mathrm{ab}} \pm 1.59$ & $11.95^{b} \pm 0.36$ & $14.78 \pm 0.58$ & NS \\
\hline $15 \mathrm{~d}$ weight $(\mathrm{kg})$ & $19.00^{\mathrm{ab}} \pm 0.20$ & $19.25^{\mathrm{ab}} \pm 0.14$ & $21.83^{\mathrm{a}} \pm 2.33$ & $17.83^{\mathrm{b}} \pm 1.88$ & $14.40^{\mathrm{c}} \pm 0.52$ & $18.31 \pm 0.73$ & $* *$ \\
\hline 30 d weight $(\mathrm{kg})$ & $22.00^{\mathrm{ab}} \pm 0.58$ & $22.63^{\mathrm{ab}} \pm 0.72$ & $24.50^{\mathrm{a}} \pm 1.76$ & $19.67^{\mathrm{c}} \pm 2.05$ & $16.43^{\mathrm{bc}} \pm 0.66$ & $20.93 \pm 0.81$ & $* *$ \\
\hline 90 d weight $(\mathrm{kg})$ & $34.75^{\mathrm{b}} \pm 3.00$ & $37.63^{\mathrm{ab}} \pm 2.89$ & $43.17^{\mathrm{a}} \pm 0.60$ & $31.17^{\mathrm{b}} \pm 0.88$ & $22.50^{\mathrm{c}} \pm 0.65$ & $33.47 \pm 1.87$ & $* * *$ \\
\hline 30 d weight gain $(\mathrm{kg})$ & $6.58^{\mathrm{ab}} \pm 1.09$ & $6.95^{\mathrm{ab}} \pm 0.59$ & $7.90^{\mathrm{a}} \pm 1.05$ & $5.00^{\mathrm{ab}} \pm 1.15$ & $4.48^{\mathrm{b}} \pm 0.69$ & $6.15 \pm 0.47$ & $*$ \\
\hline 90 d weight gain $(\mathrm{kg})$ & $12.75^{\mathrm{ab}} \pm 3.14$ & $15.00^{\mathrm{a}} \pm 2.35$ & $18.67^{\mathrm{a}} \pm 1.74$ & $11.50^{\mathrm{ab}} \pm 2.36$ & $6.08^{b} \pm 0.93$ & $12.54 \pm 1.35$ & $*$ \\
\hline $\begin{array}{l}30 \mathrm{~d} \text { daily weight gain } \\
(\mathrm{kg} / \mathrm{d})\end{array}$ & $0.285^{\mathrm{ab}} \pm 0.09$ & $0.298^{\mathrm{a}} \pm 0.08$ & $0.263^{\mathrm{a}} \pm 0.04$ & $0.167^{\mathrm{ab}} \pm 0.04$ & $0.149^{b} \pm 0.02$ & $0.234 \pm 0.03$ & $*$ \\
\hline $\begin{array}{l}90 \mathrm{~d} \text { daily weight gain } \\
(\mathrm{kg} / \mathrm{d})\end{array}$ & $0.225^{\mathrm{ab}} \pm 0.05$ & $0.250^{\mathrm{a}} \pm 0.05$ & $0.333^{\mathrm{a}} \pm 0.03$ & $0.200^{\mathrm{ab}} \pm 0.06$ & $0.100^{b} \pm 0.00$ & $0.217 \pm 0.02$ & $*$ \\
\hline
\end{tabular}

$\mathrm{NS}=P>0.05 ; *=P<0.05 ; * *=P<0.01 ; * * *=P<0.001$ 
dam groups, although lower birth weight was found in farm practice groups $\left(\mathrm{T}_{4}\right)$. Live weights of calves at 15 , 30 and $90 \mathrm{~d}$ varied significantly $(P<0.01 ; P<0.001)$ for different dam groups. In all cases, calves in farm practice group $\left(\mathrm{T}_{4}\right)$ performed poorer than calves of other dietary dam groups, while $\mathrm{T}_{2}$ groups performed significantly better than other groups. Although at 30 days age of calf, total and daily weight gain did not differ significantly $(P>0.05)$, but differ significantly $(P<0.05)$ for 90 days age among different dietary dam groups. At 90 days age of calf, weight and daily weight gain for $T_{2}$ dam groups performed better than other treatment groups.

The relationship between live weight gain and ME and $\mathrm{CP}$ intake in pre-natal RCC is shown in Figs. 1 and 2 , respectively. It was observed that live weight gain increased linearly with the increase of ME and CP intake (Figs. 1 and 2, respectively). The equations revealed that the daily maintenance requirements of $\mathrm{ME}$ and $\mathrm{CP}$ of the experimental cows were 36.19 MJ $\mathrm{ME} / \mathrm{d}$ and $433.5 \mathrm{~g} / \mathrm{d}$, respectively. The energy and protein requirements of the cows usually depends on stage of pregnancy, live weight and fetal development. Hence, ME and CP requirements for maintenance varies.

The relationship between birth weight of calves and CP intake is exhibited in Fig. 3. Fig. 3 shows the correlation between CP intake of pregnant cows and birth weight of calves, and it indicated there was a positive correlation between $\mathrm{CP}$ intake and birth weight of calves. The figure shows that per unit of $\mathrm{CP}$ intake by the dam the calf birth weight was increased by 1.77 . Diet during pregnancy is one important modifiable factor that can have a substantial influence in the viability and body composition of newborn [24]. Protein status of the mother can also impact progeny development but has not been as well studied.

Gestation length and postpartum heat period of cows of different dietary treatment groups are given in Table 5, which shows that there were no significant

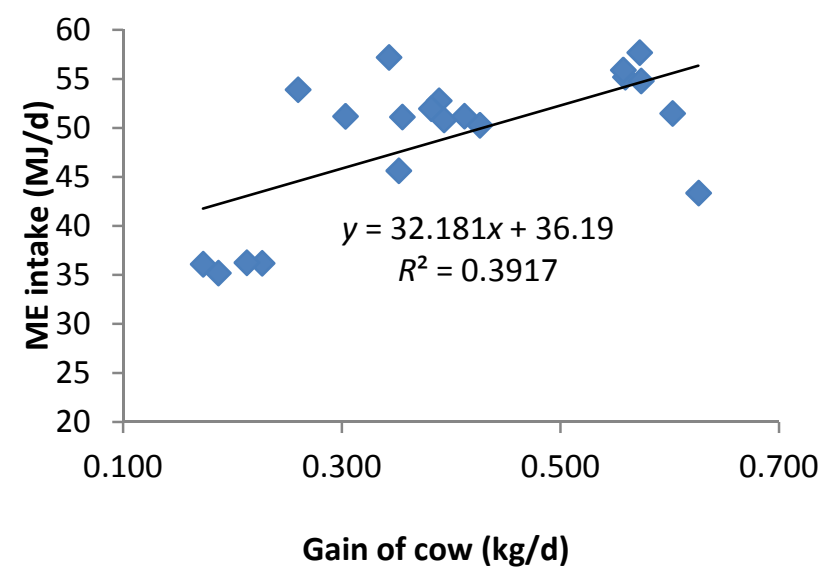

Fig. 1 Relation between ME intake and gain of pregnant cow.

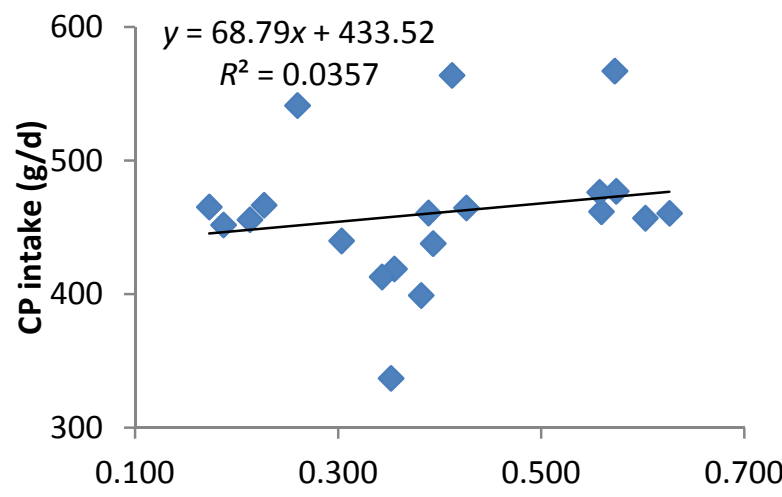

Gain of cow $(\mathrm{kg})$

Fig. 2 Relation between CP intake and body weight gain.

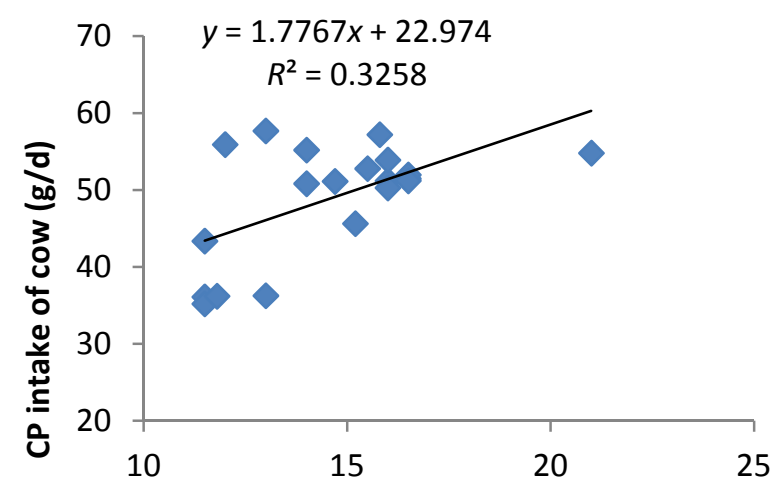

Birth weight of calf $(\mathbf{k g})$

Fig. 3 Relation between CP intake of cow and birth weight of calf. 
$(P>0.05)$ variation for those traits among cows of different dietary treatment groups, although there seems to be shorter period of postpartum heat for cows in dietary group $\mathrm{T}_{2}$ and longer period in farm practice group $\mathrm{T}_{4}$.

Milk production performance of RCC cows among different dietary groups are given in Table 6. Total and daily milk yield up to 30 days and 90 days of cows had no significant $(P>0.05)$ effect for different dietary treatment groups (Table 6), although there seems to be slightly better milk production performance for dietary group $T_{2}$ and $T_{0}$, respectively for 30 days total and daily milk yield and 90 days total and daily milk yield. However, in all cases cows in farm practice group $\mathrm{T}_{4}$ showed poorer performance.

The post-natal weight and growth changes of RCC cows for different dietary treatment groups are illustrated in Table 7.

Table 6 illustrates that there were no significant $(P>$ 0.05 ) changes of total and daily weight gain of cows for all dietary groups, however cows of $\mathrm{T}_{0}$ performed slightly better than those of cows of other dietary groups. It should also be noted that except the standard dietary group $\left(\mathrm{T}_{0}\right)$, the cows of all dietary groups showed negative weight gain during post-natal period, which may be due to the higher nutrients utilization for milk production than growth.

Milk composition of cows of different dietary treatment groups are presented in Table 8 , which shows that there were no significant $(P>0.05)$ variation on milk composition for cows of different dietary groups. Table 7 also indicates that fat content

Table 5 Gestation length and postpartum heat period of RCC.

\begin{tabular}{|c|c|c|c|c|c|c|c|}
\hline \multirow[b]{2}{*}{ Parameters } & \multicolumn{6}{|c|}{ Mean $( \pm$ SE) for different treatment groups } & \multirow[b]{2}{*}{$\begin{array}{l}\text { Sig. } \\
\text { level }\end{array}$} \\
\hline & $\begin{array}{l}\mathrm{T}_{1} \\
\text { (below 5\%) }\end{array}$ & $\begin{array}{l}\mathrm{T}_{0} \\
\text { (standard) }\end{array}$ & $\begin{array}{l}\mathrm{T}_{2} \\
\text { (above 5\%) }\end{array}$ & $\begin{array}{l}\mathrm{T}_{3} \\
\text { (above 10\%) }\end{array}$ & $\begin{array}{l}\mathrm{T}_{4} \\
\text { (farm practice) }\end{array}$ & Overall & \\
\hline Gestation length (d) & $283.3 \pm 1.70$ & $283.0 \pm 2.12$ & $283.7 \pm 0.67$ & $282.0 \pm 0.58$ & $282.0 \pm 0.41$ & $282.8 \pm 0.58$ & NS \\
\hline $\begin{array}{l}\text { Postpartum heat } \\
\text { period (d) }\end{array}$ & $58.5 \pm 4.98$ & $75.8 \pm 11.31$ & $36.5 \pm 12.20$ & $40.3 \pm 13.62$ & $93.3 \pm 33.08$ & $60.9 \pm 8.61$ & NS \\
\hline
\end{tabular}

$\mathrm{NS}=P>0.05$.

Table 6 Feeding effect on milk yield of pre-post RCC.

\begin{tabular}{|c|c|c|c|c|c|c|c|}
\hline \multirow[b]{2}{*}{ Parameters } & \multicolumn{6}{|c|}{ Mean $( \pm \mathrm{SE})$ for different treatment groups } & \multirow[b]{2}{*}{ Sig. } \\
\hline & $\begin{array}{l}\mathrm{T}_{1} \\
\text { (below 5\%) }\end{array}$ & $\begin{array}{l}\mathrm{T}_{0} \\
\text { (standard) }\end{array}$ & $\begin{array}{l}\mathrm{T}_{2} \\
(\text { above 5\%) }\end{array}$ & $\begin{array}{l}\mathrm{T}_{3} \\
\text { (above 10\%) }\end{array}$ & $\begin{array}{l}\mathrm{T}_{4} \\
\text { (farm practice) }\end{array}$ & Overall & \\
\hline $\begin{array}{l}\text { Total milk yield up to one } \\
\text { month }(\mathrm{kg})\end{array}$ & $104.2 \pm 18.88$ & $132.2 \pm 17.58$ & $143.0 \pm 13.29$ & $107.0 \pm 21.30$ & $121.2 \pm 3.84$ & $121.1 \pm 7.14$ & NS \\
\hline $\begin{array}{l}\text { Daily average milk yield } \\
\text { up to one month }(\mathrm{kg} / \mathrm{d})\end{array}$ & $3.54 \pm 0.59$ & $4.70 \pm 0.31$ & $4.77 \pm 0.44$ & $3.57 \pm 0.71$ & $4.04 \pm 0.13$ & $4.12 \pm 0.22$ & NS \\
\hline $\begin{array}{l}\text { Total milk yield up to three } \\
\text { months }(\mathrm{kg})\end{array}$ & $245.5 \pm 39.17$ & $349.8 \pm 34.59$ & $278.0 \pm 71.15$ & $266.2 \pm 76.63$ & $274.7 \pm 17.88$ & $285.1 \pm 19.46$ & NS \\
\hline $\begin{array}{l}\text { Daily average milk yield } \\
\text { up to three months }(\mathrm{kg} / \mathrm{d})\end{array}$ & $2.73 \pm 0.44$ & $3.89 \pm 0.38$ & $3.09 \pm 0.79$ & $1.97 \pm 1.10$ & $3.05 \pm 0.19$ & $2.99 \pm 0.27$ & NS \\
\hline
\end{tabular}

$\mathrm{NS}=P>0.05$.

Table 7 Post-natal growth of RCC.

\begin{tabular}{|c|c|c|c|c|c|c|c|}
\hline \multirow[b]{2}{*}{ Parameters } & \multicolumn{6}{|c|}{ Mean $( \pm$ SE $)$ for different treatment groups } & \multirow[b]{2}{*}{ Sig. } \\
\hline & $\begin{array}{l}\mathrm{T}_{1} \\
\text { (below 5\%) }\end{array}$ & $\begin{array}{l}\mathrm{T}_{0} \\
\text { (standard) }\end{array}$ & $\begin{array}{l}\mathrm{T}_{2} \\
\text { (above 5\%) }\end{array}$ & $\begin{array}{l}\mathrm{T}_{3} \\
\text { (above 10\%) }\end{array}$ & $\begin{array}{l}\mathrm{T}_{4} \\
\text { (farm practice) }\end{array}$ & Overall & \\
\hline Initial weight (kg) & $168.13 \pm 10.42$ & $196.25 \pm 8.69$ & $141.63 \pm 50.25$ & $138.50 \pm 49.13$ & $182.00 \pm 8.69$ & $165.30 \pm 13.81$ & NS \\
\hline Final weight (kg) & $167.88 \pm 11.38$ & $197.50 \pm 10.87$ & $141.00 \pm 49.99$ & $136.00 \pm 47.69$ & $176.25 \pm 6.87$ & $163.73 \pm 13.69$ & NS \\
\hline Total weight gain $(\mathrm{kg})$ & $-0.25 \pm 1.23$ & $1.25 \pm 3.24$ & $-0.625 \pm 0.68$ & $-2.500 \pm 2.84$ & $-5.750 \pm 2.53$ & $-1.575 \pm 1.08$ & NS \\
\hline Daily weight gain $(\mathrm{kg} / \mathrm{d})$ & $-0.009 \pm 0.04$ & $0.046 \pm 0.11$ & $-0.021 \pm 0.02$ & $-0.083 \pm 0.09$ & $-0.192 \pm 0.08$ & $-0.052 \pm 0.04$ & NS \\
\hline
\end{tabular}

$\mathrm{NS}=P>0.05$. 
Table 8 Feeding effect on milk composition of RCC.

\begin{tabular}{|c|c|c|c|c|c|c|c|}
\hline \multirow[b]{2}{*}{ Parameters } & \multicolumn{6}{|c|}{ Mean $( \pm \mathrm{SE})$ for different treatment groups } & \multirow[b]{2}{*}{$\begin{array}{l}\text {-Sig. } \\
\text { level }\end{array}$} \\
\hline & $\begin{array}{l}\mathrm{T}_{1} \\
\text { (below 5\%) }\end{array}$ & $\begin{array}{l}\mathrm{T}_{0} \\
\text { (standard) }\end{array}$ & $\begin{array}{l}\mathrm{T}_{2} \\
\text { (above 5\%) }\end{array}$ & $\begin{array}{l}\mathrm{T}_{3} \\
\text { (above 10\%) }\end{array}$ & $\begin{array}{l}\mathrm{T}_{4} \\
\text { (farm practice) }\end{array}$ & Overall & \\
\hline Fat content $(\%)$ & $4.64^{\mathrm{ab}} \pm 0.76$ & $4.79^{\mathrm{ab}} \pm 0.38$ & $5.93^{\mathrm{a}} \pm 0.46$ & $3.46^{\mathrm{b}} \pm 1.19$ & $4.60^{\mathrm{ab}} \pm 0.26$ & $4.62 \pm 0.34$ & $*$ \\
\hline Protein content $(\%)$ & $4.08 \pm 0.09$ & $4.04 \pm 0.04$ & $4.03 \pm 0.11$ & $3.03 \pm 1.01$ & $3.94 \pm 0.08$ & $3.81 \pm 0.21$ & NS \\
\hline Lactose content $(\%)$ & $5.84 \pm 0.17$ & $5.68 \pm 0.11$ & $5.56 \pm 0.06$ & $4.15 \pm 1.39$ & $5.46 \pm 0.14$ & $5.33 \pm 0.30$ & NS \\
\hline SNF content $(\%)$ & $8.29 \pm 2.25$ & $10.72 \pm 0.07$ & $10.31 \pm 0.11$ & $7.92 \pm 2.64$ & $10.58 \pm 0.13$ & $9.52 \pm 0.71$ & NS \\
\hline Mineral content $(\%)$ & $0.20^{\mathrm{a}} \pm 0.05$ & $0.16^{\mathrm{ab}} \pm 0.04$ & $0.23^{\mathrm{a}} \pm 0.03$ & $0.08^{\mathrm{b}} \pm 0.04$ & $0.19^{\mathrm{ab}} \pm 0.01$ & $0.17 \pm 0.02$ & $*$ \\
\hline
\end{tabular}

$\mathrm{NS}=P>0.05$. SNF $=$ Solid's not-fat; $*=P<0.05$.

Table 9 Post-natal BCS of RCC.

\begin{tabular}{|c|c|c|c|c|c|c|c|}
\hline \multirow[b]{2}{*}{ Parameters } & \multicolumn{6}{|c|}{ Mean $( \pm \mathrm{SE})$ for different treatment groups } & \multirow{2}{*}{$\begin{array}{l}\text {-Sig. } \\
\text { level }\end{array}$} \\
\hline & $\begin{array}{l}\mathrm{T}_{1} \\
\text { (below 5\%) }\end{array}$ & $\begin{array}{l}\mathrm{T}_{0} \\
\text { (standard) }\end{array}$ & $\begin{array}{l}\mathrm{T}_{2} \\
\text { (above 5\%) }\end{array}$ & $\begin{array}{l}\mathrm{T}_{3} \\
\text { (above 10\%) }\end{array}$ & $\begin{array}{l}\mathrm{T}_{4} \\
\text { (farm practice) }\end{array}$ & Overall & \\
\hline BCS on month one & $3.90^{\mathrm{a}} \pm 0.15$ & $3.63^{\mathrm{a}} \pm 0.30$ & $4.06^{\mathrm{a}} \pm 0.18$ & $3.68^{\mathrm{a}} \pm 0.29$ & $2.98^{b} \pm 0.09$ & $3.65 \pm 0.12$ & * \\
\hline BCS on month two & $3.98^{\mathrm{a}} \pm 0.23$ & $3.75^{\mathrm{ab}} \pm 0.19$ & $4.13^{\mathrm{a}} \pm 0.24$ & $3.78^{\mathrm{ab}} \pm 0.27$ & $3.18^{\mathrm{b}} \pm 0.12$ & $3.76 \pm 0.11$ & $*$ \\
\hline BCS on month three & $3.94^{\mathrm{a}} \pm 0.21$ & $3.78^{\mathrm{ab}} \pm 0.16$ & $4.10^{\mathrm{a}} \pm 0.06$ & $3.98^{\mathrm{a}} \pm 0.21$ & $3.35^{\mathrm{b}} \pm 0.09$ & $3.83 \pm 0.09$ & $*$ \\
\hline BCS on month four & $4.03^{\mathrm{a}} \pm 0.10$ & $3.98^{\mathrm{a}} \pm 0.25$ & $4.15^{\mathrm{a}} \pm 0.13$ & $4.10^{\mathrm{a}} \pm 0.15$ & $3.43^{\mathrm{b}} \pm 0.05$ & $3.94 \pm 0.09$ & $*$ \\
\hline
\end{tabular}

$*=P<0.05$.

found in milk of group $T_{2}$ was slightly better than those of other groups, while poorer in group $T_{3}$. Protein content was found slightly better in milk of group $T_{1}$ than those of other groups, while poorer in group $T_{3}$. Lactose content was found slightly better in milk of group $T_{1}$ than those of other groups while poorer in group $T_{3}$. Similarly solid's not-fat (SNF) and mineral contents were found slightly better in groups $T_{0}$ and $T_{2}$, respectively, than those of rests of the groups, while poorer in groups $\mathrm{T}_{3}$ for both parameters.

Table 9 indicates the post-natal BCS of cows of different dietary treatment groups. Post-natal BCS for 1st, 3rd and 4th months differed significantly $(P<$ 0.05 ) among different dietary groups, while not found significant difference on 2nd month (Table 8). It should be mentioned here that in all cases cows in group $T_{2}$ performed better than those of other groups, while cows in farm practice group $\left(\mathrm{T}_{4}\right)$ performed worse than those of other groups (Table 8). Banos et al. [25] observed that daughters of older dam had lower BCS, produced less milk yield and needed more days to first service. Banos et al. [25] also found that daughters from late calving first parity cows (30-36 months) had a $7 \%$ lower BCS, produced $4.5 \%$ less milk, and had their first service almost 3 days later than daughters from early calving first parity cows (18-32 months).

\section{Conclusions}

In conclusion, it was observed that pre-natal feeding above $5 \%$ protein and energy in the diet of dairy cows have significantly increased the body weight gain, birth weight of calves and milk production of dairy cows; and reduced post-partum heat period. Therefore, it is suggested that better nutrition may be provided during pre-natal period to harvest good quality of calves and higher milk yield from post-natal period.

\section{References}

[1] Mudgal, V. D., Singhal, K. K., and Sharma, D. D. 1995. Advances in Dairy Animal Production, 1st ed.. Lucknow, India: International Book Distribution Company, 21-32.

[2] Kale, M. M. 1984. "Effects of Prepartum Feeding on the Post Partum Performance of Crossbred Cows." M.Sc. thesis, Kurukshera University, Kurukshetra, India.

[3] Prasad, S., and Tomer, O. S. 1995. "Effect of Prepartum Level of Conditioning on Certain Calving and Related Parameters on Crossbred Calves." Indian J. Anim. Pro. Mgmt. 11: 139-42.

[4] Khan, M. A., Islam, M. N., Khan, M. A. S., and Akbar, M. A. 2004. "Effect of Feeding High and Low Energy Levels during Late Pregnancy on Performance of Crossbred Dairy Cows and Their Calves." Asian Austr. J. 


\section{Pregnant Mother and Neo-Natal Calves}

Anim. Sci. 17 (7): 947-53.

[5] Bhuiyan, A. K. F. H., Hossain, M. M., and Deb, G. K. 2007. "Indigenous Cattle Genetic Resources of Bangladesh and a Way forward to Their Development." Bangdesh J. Prog. Sci. \& Tech. 5 (1): 105-12.

[6] Islam, S. S. 2010. "Development of Feeding System for Improving Productive Performance of Red Chittagong Cattle of Bangladesh." Ph.D. thesis, Department of Animal Nutrition, BAU, Mymensingh.

[7] Ahmed, T. U. 2006. "Studies on Nutritional Status of Dairy Cows of Bangladesh and Improvement of Their Productive and Reproductive Performance in Baghabarighat Area through Nutritional Manipulation.” Ph.D. thesis, Department of Animal Nutrition, BAU, Mymensingh.

[8] Ziegler, K. 2009. "Management in the Last Trimester of Pregnancy." Ag-Info Centre, Toll-free in Alberta at 310-FARM (3276). Accessed May 25, 2015. www.agri.gov.ab.ca/app8/processsearch?action=7\&search =Ziegler.

[9] Barker, D. J. P. 2004. "Developmental Origins of Well-Being Philos." Trans. R. Soc. Lond. B. Biol. Sci. 359: 1359-66.

[10] Wu, G., Bazer, F. W., Wallace, J. M., and Spencer, T. E. 2006. "Intrauterine Growth Retardation: Implications for the Animal Sciences.” J. Anim. Sci. 84 (9): 2316-37.

[11] Wallace, L. R. 1948. "The Growth of Lambs before and after Birth in Relation to the Level of Nutrition.” J. Agri. Sci. 38 (3): 243-300.

[12] Wallace, J. M., Bourke, D. A., and Aitken, R. P. 1999. "Nutrition and Fetal Growth: Paradoxical Effects in the Overnourished Adolescent Sheep." J. Reprod. Fertil. 54: 385-99.

[13] Godfrey, K. M., and Barker, D. J. 2000. "Fetal Nutrition and Adult Disease." Am. J. Clin. Nutr. 71: 1344-52.

[14] Bull, S., and Carroll, W. E. 1937. Principles of Feeding Farm Animals. New York: The MacMillan Company,
65-70.

[15] Barcroft, J. 1946. Researches on Pre-Natal Life. Oxford: Blackwell Scientific Pub., 73-5.

[16] Morrison, F. 1949. Feeds and Feeding: A Handbook for the Student and Stockman, 21st ed.. Ithaca: the Morrison Publishing Company, 23-7.

[17] Maynard, L. A., and Loosli, J. K. 1956. Animal Nutrition. New York: McGraw-Hill Book Company, 40-4.

[18] Cramption, E. W., and Lloyd, L. E. 1959. Fundamentals of Nutrition. San Francisco: W. H. Freeman and Company, 21-3.

[19] National Research Council (NRC). 1970. Maternal Nutrition and the Course of Pregnancy. Washington, D.C.: National Academy of Science, 62-3.

[20] Shamsuddin, M., Alam, M. G. S., and Ahmed, J. U. 1988. "Reproductive Disorders of Crossbred Cows." Bangladesh Vet. J. 22: 21-8.

[21] Lotthammer, K. H. 1996. "Importance of $\beta$-Carotene for Fertility of Dairy Cattle." Feedstuff 51: 16-50.

[22] Jalil, M. A., Sarker, N. R., Paul, D. C., and Khan, A. A. 1995. "Status of Existing Husbandry Practices of Dairy Cattle at Manikganj, Bangladesh." Bangladesh J. Anim. Sci. 24 (1-2): 71-80.

[23] Asaduzzaman, M., Alam, M. R., Huque, K. S., and Sarker, N. R. 2011. "Study on Feeding Effect of Productive and Reproductive Performances of Pregnant and Lactating RC Cows in Selected Breeding Habitat of Satkania Upazila under Chittagong District." In Proceeding of the Annual Research Review Workshop, 209-93.

[24] Symonds, M. E., Sebert, S. P., and Budge, H. 2010. "Nutritional Regulation of Fetal Growth and Implications for Productive Life in Ruminants." Animal 4 (7): 1075-83.

[25] Banos, G., Brotherstone, S., and Coffey, M. P. 2007. "Pre-natal Maternal Effects on Body Condition Score, Female Fertility and Milk Yield of Dairy Cows." J. Dairy Sci. 90 (7): 3490-9. 